UDK $\quad 662.762 .2: 633.1-027.33$

DOI: https://doi.org/

A. Makarynska, PhD. Sc., Ass. Professor, E-mail: allavm2015@gmail.com ORCID: 0000-0003-1879-8455, Researcher ID: C-5217-2016, Scopus ID: 57192819060 T. Turpurova, PhD. Sc., Ass. Professor, E-mail: turpurova.tatyana@gmail.com ORCID 0000-0003-3030-7591, Researcher ID: C-3755-2017 V. Buluk, Postgraduate Student, E-mail: vbuliuk@gmail.com Department of Feed and Biofuel Technologies,

Odessa National Academy of Food Technologies, 112, Kanatna Str., Odessa, 65039, Ukraine, +380487124113

\title{
PRODUCTION OF SOLID BIOFUELS FROM GRAIN PROCESSING WASTES
}

\begin{abstract}
The article is devoted to the issues of solid biofuel production. The classification of biomass used in the production of solid biofuels by origin is given. The main types of grain waste in the southern region for the production of solid biofuels are identified.

The article analyzes the soybean market in the world and Ukraine, shows the trend of growing soybean production, which is caused by the growing demand for food and feed purposes. Soybean yield indicators in Ukraine are analyzed and it is found that Kherson region is one of the leaders of soybean yields for 2019. It is shown that in soybean cultivation in Ukraine a considerable amount of secondary resource is obtained - straw, as a by-product of crop production. It is established that the average yield of rice of Kherson region prevails in Ukraine, a large amount of rice husk is formed during processing of raw rice.

Physico-mechanical properties of rice husk and soybean straw have been determined. The possibility of production of fuel briquettes from the waste was considered, technological scheme of production of fuel briquettes from waste, which are formed at the enterprises of processing industry and by-products of crop production is given.

The technology of production of fuel briquettes from soy straw and rice husk was introduced at the enterprise of Kherson region, which is engaged in cultivation and processing of soybeans and rice. Quality indicators of fuel briquettes were determined: humidity, ash, sulfur, carbon content, volatile matter yield and specific combustion heat. It is established that the quality of fuel pellets is significantly influenced by humidity, degree of grinding and physical and chemical properties of raw materials. When the moisture content of raw materials more than 14\% decreases the density of the granules and, due to the evaporation of moisture, cracks appear in the granules, which reduce their strength. With the reduction of the average particle size of the biomass to $2 \mathrm{~mm}$, the quality of the fuel products increases, but the fine fraction of the biomass of the matrix is erased.

The heat of combustion of the obtained solid briquettes exceeds the normative values of European standards at a level not lower than $18 \mathrm{MJ} / \mathrm{kg}$. Ash content (0.5\%), normalized by European standards, is practically unavailable for Ukrainian producers, fuel briquettes made from soy straw and husks have higher normalized ash values in accordance with 7.0 and $14.0 \%$, which reduces their quality indicators.
\end{abstract}

Keywords: waste, rice husk, soybean straw, technology, biofuels, briquettes, quality.

\section{Introduction. Formulation of the problem}

Today, Ukraine remains an energy-scarce state, covering its energy needs by approximately $53 \%$, while importing $75 \%$ of the required volume of natural gas and $85 \%$ of crude oil and petroleum products $[1,2]$.

Primary energy shortages should be actively covered by renewable energy sources. Biomass is a significant component of renewable energy sources and has great potential, attracting which can satisfy $13-15 \%$ of the state's demand for primary energy [3, 4].

According to the Best Practices and Methods Handbook of BEE - Biomass Energy Europe, there are four categories of biomass for energy use. In Fig. 1 shows the classification of biomass by its origin $[5,6]$.

Agrobiomass includes waste from agriculture, food and grain processing industries. The greatest potential of agrobiomass is in the central, southern and southeastern regions of Ukraine, where agriculture and the food processing sector are developed. The total potential of wood biomass in 2016 was 1378 thousand tons of oil equivalent, agrobiomass - 8039 thousand tons of oil equivalent [7]. The potential of wood biomass depends on the level of development of the wood processing industry in the region, as well as on the level of logging. For agrobiomass, the main factor affecting the potential is the annual yield of agricultural crops, which fluctuates significantly depending on the climatic conditions every year.

\section{The purpose and objectives of the study}

The purpose of the work is the development and implementation of technology for the production of solid fuel briquettes from grain processing waste.

To achieve this goal it is necessary to define the following tasks:

- substantiate the choice of raw materials for the production of solid fuel briquettes;

- to develop a scheme of technological process of production of solid fuel briquettes from grain processing waste; 


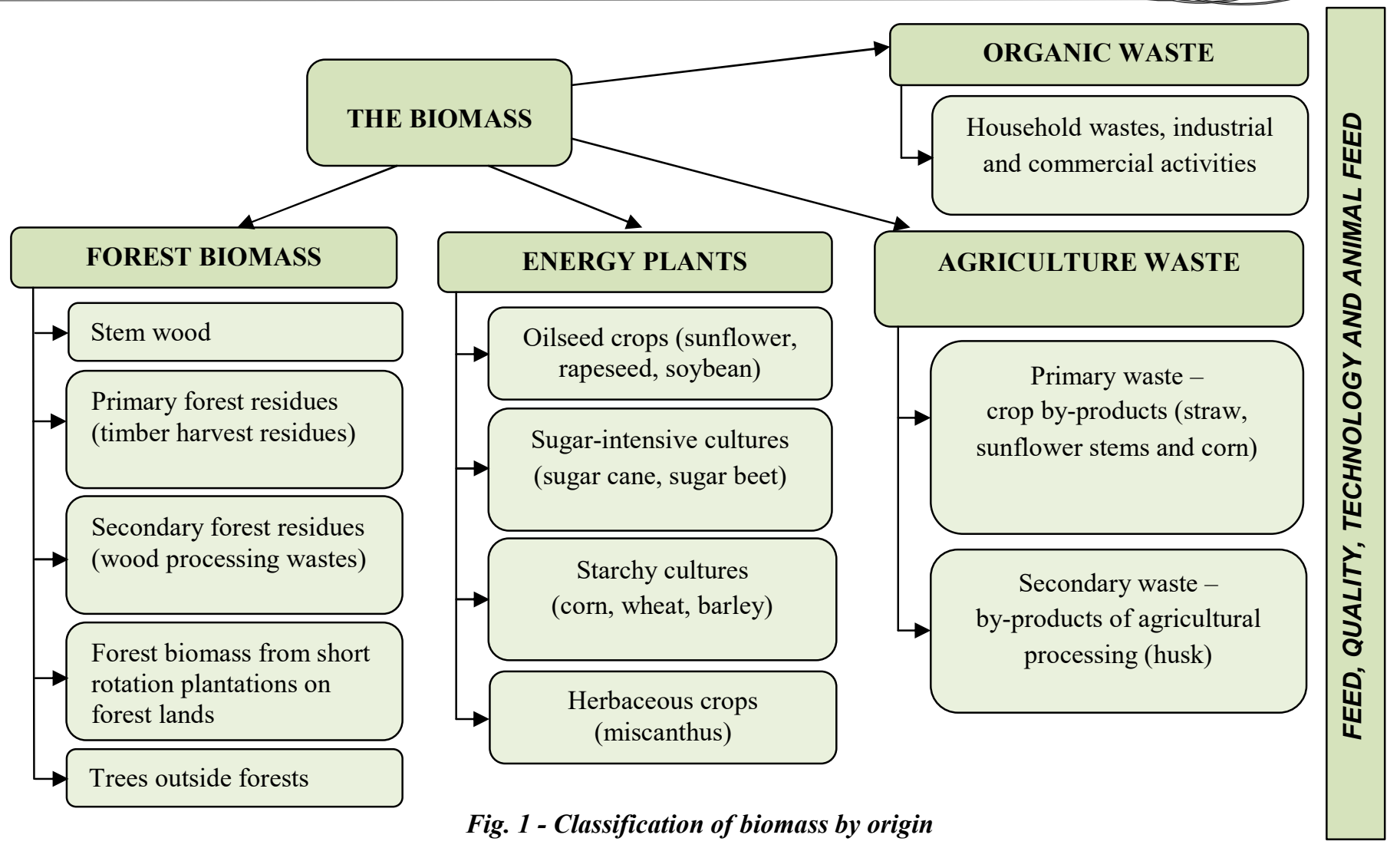

- determine the physical properties of raw materials for the production of solid fuel briquettes;

- introduce the technology of production of solid fuel briquettes from soybean straw and rice husk at the enterprise;

- determine the fuel characteristics of solid soybean briquettes and rice husks.

\section{Literature review}

In Ukraine, more than 50 million tonnes of cereals are harvested annually, with straw and vegetable waste as a by-product of agricultural crop, respectively. The annual technically achievable energy potential of solid biomass in Ukraine is equivalent to 18 million tonnes, and its use makes it possible to save about 22 billion cubic meters annually of natural gas. To determine the yield of straw and plant residues use the coefficient of waste - the ratio of straw yields or stems of plants to grain yield. According to various estimates, 1.52.0 tonnes of straw or vegetable residues can be obtained per ton of grain [8].

Soybeans are traditionally referred to as one of the most common leguminous crops in the world, sowing more than 120 million hectares each year. The leaders of soybean cultivation are the USA, Brazil, Argentina. It should be noted that the United States produces 120.5 million tonnes, which is more than $30 \%$ of world soybeans (Fig. 2) [9, 10].

Ukraine is the leader in soybean production in Europe and ranks 9th in the production of legumes in the world. The price of Ukrainian soybeans for export is 348 US. USD / $t$ is the lowest among the leaders of producers - USA, Brazil and Argentina (Fig. 3) [10].

The soybean market is one of the most important for Ukraine's agricultural production. Over the

past 10 years, soybean acreage has more than tripled, reaching 3.7 million hectares (as of 2019), accounting for

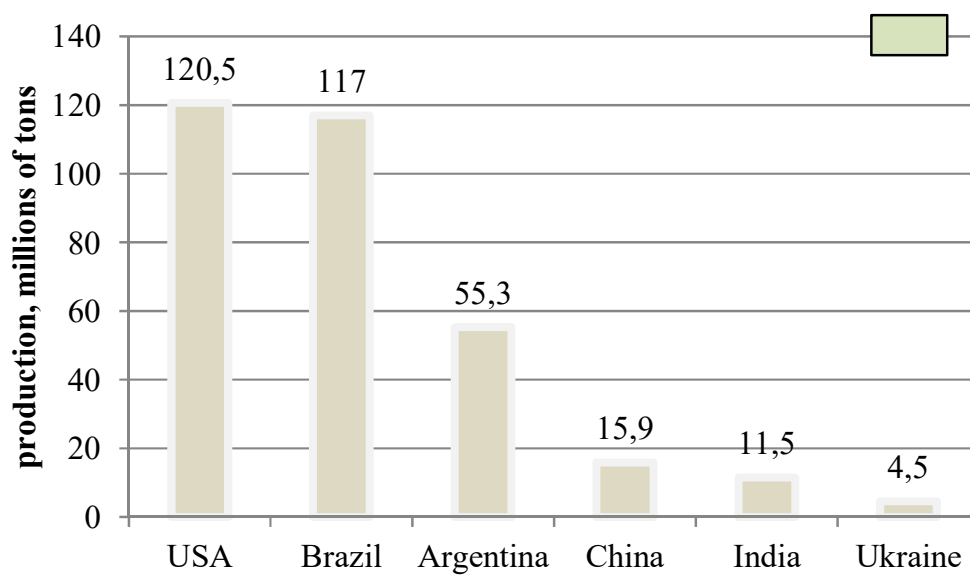

Fig. 2 - The world's largest soybean producers

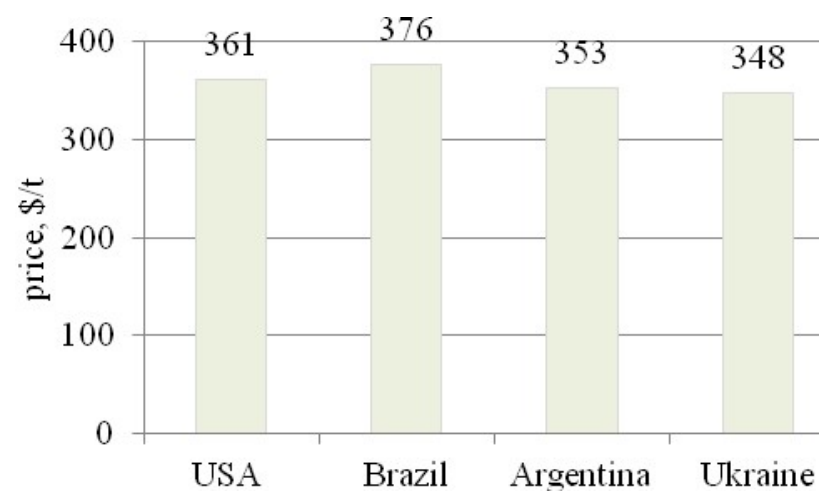

Fig. 3 - Cost of soybean grain by major exporters (as of October 2019) [10] 


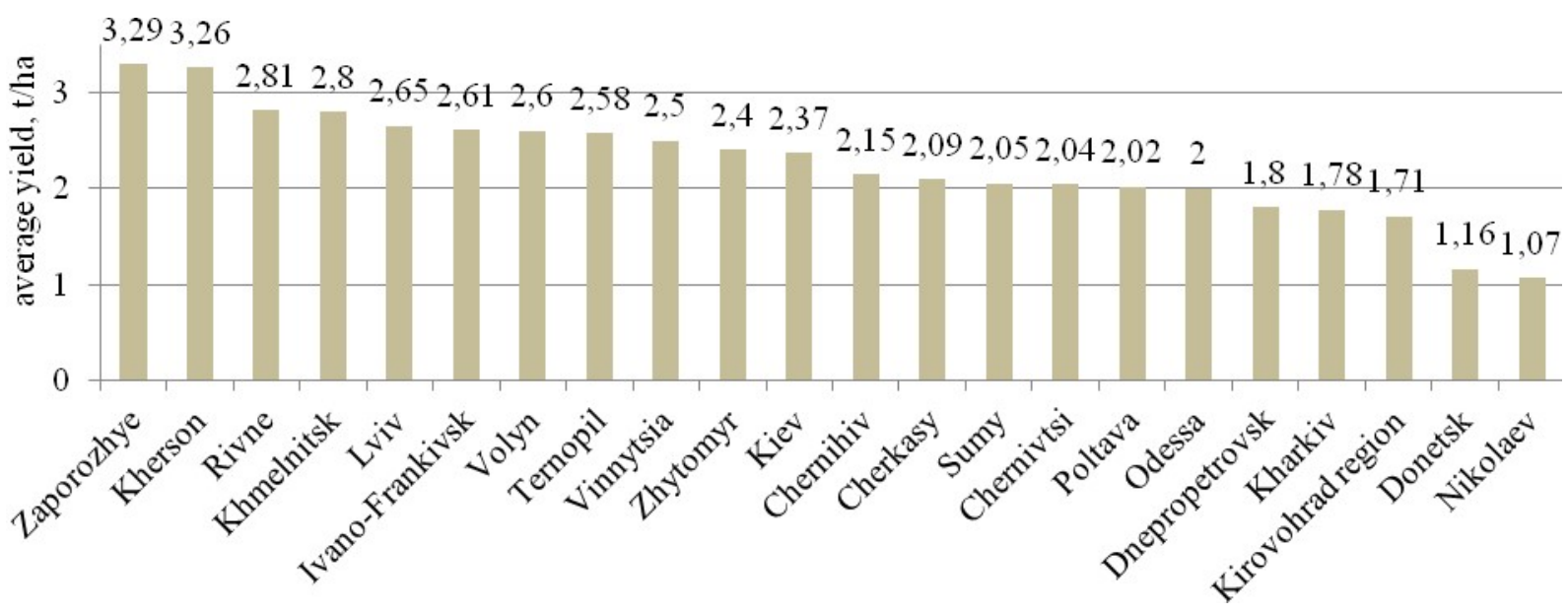

Fig. 4 - Rating of areas by average soybean yield (as of September 20, 2019)

$8.5 \%$ of all crop area. In 2019, soybeans harvested 3.7 million tonnes with an average yield of 2.35 tonnes / ha. The highest soybean yields were recorded in the farms of Zaporizhzhia (3.29 t/ ha), Kherson (3.26 t/ ha) and Rivne (2.81 t / ha) regions (Fig. 4) [11].

As the Kherson region holds the leading position in Ukraine on soybean yields, straw is the main source of biomass in the region, as the primary waste of soybean processing. It is advisable to use soybean straw:

$\checkmark$ as an organic fertilizer to support soil fertility;

$\checkmark$ for the needs of animal husbandry as rough animal feed and litter;

$\checkmark$ for energy needs.

Another type of agricultural biomass waste is secondary waste that is generated by grain processing companies. Such waste, characteristic of the Kherson region, can be attributed to rice husk. About 600 million tonnes of rice husk are produced annually in the world as a result of threshing. Utilization of rice husk is an urgent problem worldwide, especially in countries where rice is a major cereal product (China, India, Egypt, South Korea, Africa, Uzbekistan).

The rice husk accumulates at the raw rice processing plants located near this crop. As of the beginning of November-2019, the average yield of rice in the Kherson region was $62 \mathrm{c} / \mathrm{ha}$, while in Ukraine it was $58 \mathrm{c} /$ ha [11].

\section{Object and subject of research}

The objects of the research were raw materials: rice husk, straw (soybean) soybeans and solid fuel briquettes from them, which were obtained in the production conditions of LLC "Agrofirm Bulyuk" (Kherson region). The subject of research was the technology of production of solid fuel briquettes from grain waste.

The main physical and mechanical properties of sealing materials, which depend on the choice of technological modes of production and quality of solid fuel briquettes include: mass fraction of moisture, fractional composition, content and type of constituent components, which were determined by standard methods [15], the qualitative indicators of fuel characteristics of
Table 1 - Methods for determining the fuel characteristics of briquettes

\begin{tabular}{||l||l||}
\hline \multicolumn{1}{|c||}{ Parameters } & \multicolumn{1}{c|}{ Method of determination } \\
\hline \hline $\begin{array}{l}\text { Moisture } \\
\text { content, \% }\end{array}$ & $\begin{array}{l}\text { GOST R 54186-2010 «Solid biofu- } \\
\text { els. Determination of moisture con- } \\
\text { tent by drying. Part 1. Total mois- } \\
\text { ture. Standard Method» in an auto- } \\
\text { matic humidifier to a constant mass } \\
\text { of samples at a temperature of } \\
+40^{\circ} \mathrm{C} \text { and }+105^{\circ} \mathrm{C} \text {. }\end{array}$ \\
\hline \hline Ash content, \% & $\begin{array}{l}\text { GOST R 54185-2010 «Solid } \\
\text { biofuels. Ash determination» by } \\
\text { annealing the dried sample sample } \\
\text { in the presence of air at }+550{ }^{\circ} \mathrm{C} .\end{array}$ \\
\hline \hline $\begin{array}{l}\text { Carbon and } \\
\text { sulfur content, } \\
\%\end{array}$ & $\begin{array}{l}\text { The determination was carried out } \\
\text { on a carbon and sulfur analyzer } \\
\text { based on the combustion products } \\
\text { of Leco CS } 230 .\end{array}$ \\
\hline \hline $\begin{array}{l}\text { The yield of } \\
\text { volatile sub- } \\
\text { stances, \% }\end{array}$ & $\begin{array}{l}\text { It was determined by the mass loss } \\
\text { during rapid heating of the samples } \\
\text { to }+420^{\circ} \mathrm{C} \text { without air access. }\end{array}$ \\
\hline \hline $\begin{array}{l}\text { Calorie } \\
\text { parameters, } \\
\text { kcal / kg }\end{array}$ & $\begin{array}{l}\text { The determination and samples } \\
\text { were performed on the IKA C2000 } \\
\text { calorimeter according to its } \\
\text { instruction, which meets the } \\
\text { requirements of GOST 147-95. }\end{array}$ \\
\hline \hline
\end{tabular}

briquettes were determined by standard methods according to table. 1 .

\section{Results and its discussion}

Primary and secondary wastes play a significant role in the production of solid fuel briquettes. The results of determining the physical and mechanical properties of the raw material - rice husks and soybeans (soybeans) are presented in Table. 2, which shows that the sealing materials are not of a permanent nature, and therefore may differently manifest themselves depending on various factors and directly affect the quality of finished solid fuel briquettes. Moisture content of $10.0 \ldots 11.5 \%$ indicates that fuel briquettes can be obtained by dry briquetting. 
Table 2 - Physical indicators of raw materials

\begin{tabular}{||l||c||c||}
\hline \multicolumn{1}{|c||}{ Parameters } & Rice husk & Straw (soybean) soy \\
\hline \hline Bulk mass, $\mathrm{kg} / \mathrm{m}^{3}$ & 125 & 55 \\
\hline \hline $\begin{array}{l}\text { Moisture } \\
\text { content, } \%\end{array}$ & 10,0 & 11,5 \\
\hline \hline Particle size, $\mathrm{mm}$ & 6 & 22 \\
\hline \hline Density, $\mathrm{t} / \mathrm{m}^{3}$ & 1,01 & 0,75 \\
\hline
\end{tabular}

The technology of production of solid fuel briquettes from soybean straw and husks of rice was introduced at the enterprise of LLC "Agrofirm Bulyuk" (Kherson region), which is engaged in growing soybeans and rice. The technological scheme of production of solid fuel briquettes is presented in fig. 5 and includes the following technological operations: receiving, grinding, calibration, drying of raw materials, pressing of raw materials into briquettes, cooling and packaging $[5,12,13]$.

Acceptance of raw materials.

Raw materials are received at the site, the dimensions of which should allow at least daily accumulation of biomass to be accumulated to ensure timely and uninterrupted feed for further processing. It should be borne in mind that if straw is used as feedstock, it may be packed in rectangular bales or rolls that cannot be manually moved, it is advisable to use a cargo trolley. Therefore, the equipment of the site may include auxiliary equipment for biomass transportation. If the briquetting line has low capacity and is located near the source of raw materials, then the raw materials can be delivered in the form of straw or crushed corn stalks, that is, it is possible to eliminate the stage of agrobiomass baling and save on it.
Grinding of raw materials.

At the preparation stage, the grinding of raw materials is carried out to a fraction that meets the requirements of certain briquetting equipment. It is also necessary to ensure the absence of extraneous inclusions in the raw material (metal impurities, stones, sand).

Raw material calibration.

Calibration is required to separate the raw material with the required size of the fractional composition. Drum calibrators with sieve openings up to 5-6 $\mathrm{mm}$ are used for the implementation of this technological operation. Some manufacturers use sieve shredders to perform biomass calibration.

\section{Drying of crushed raw materials.}

The crushed raw material enters the chamber of the drying unit. The extraction of excess moisture is carried out by hot air produced by the heat generator, which can operate both on the biomass itself and on natural gas. Usually raw materials need to be dried to a moisture content of $8-14 \%$. There are press briquettes with the possibility of using biomass up to $30 \%$ humidity, which can be achieved with proper storage of biomass, and therefore there is no need for a drying operation. Subsequently, the crushed and dried material enters the battery cyclone, where its separation with the coolant occurs. The spent coolant is released into the atmosphere and the dried material is fed to the feeder of the press briquette.

Pressing raw materials into briquettes

The formation of a crushed plant mass of strong briquettes is ensured both by the physico-mechanical properties of the material and by the conditions of the briquetting process itself. There are certain requirements for the quality of the briquette that must be met. This is, first of all, the density of the briquette $(0.8-1.3 \mathrm{t} / \mathrm{m} 3)$, its
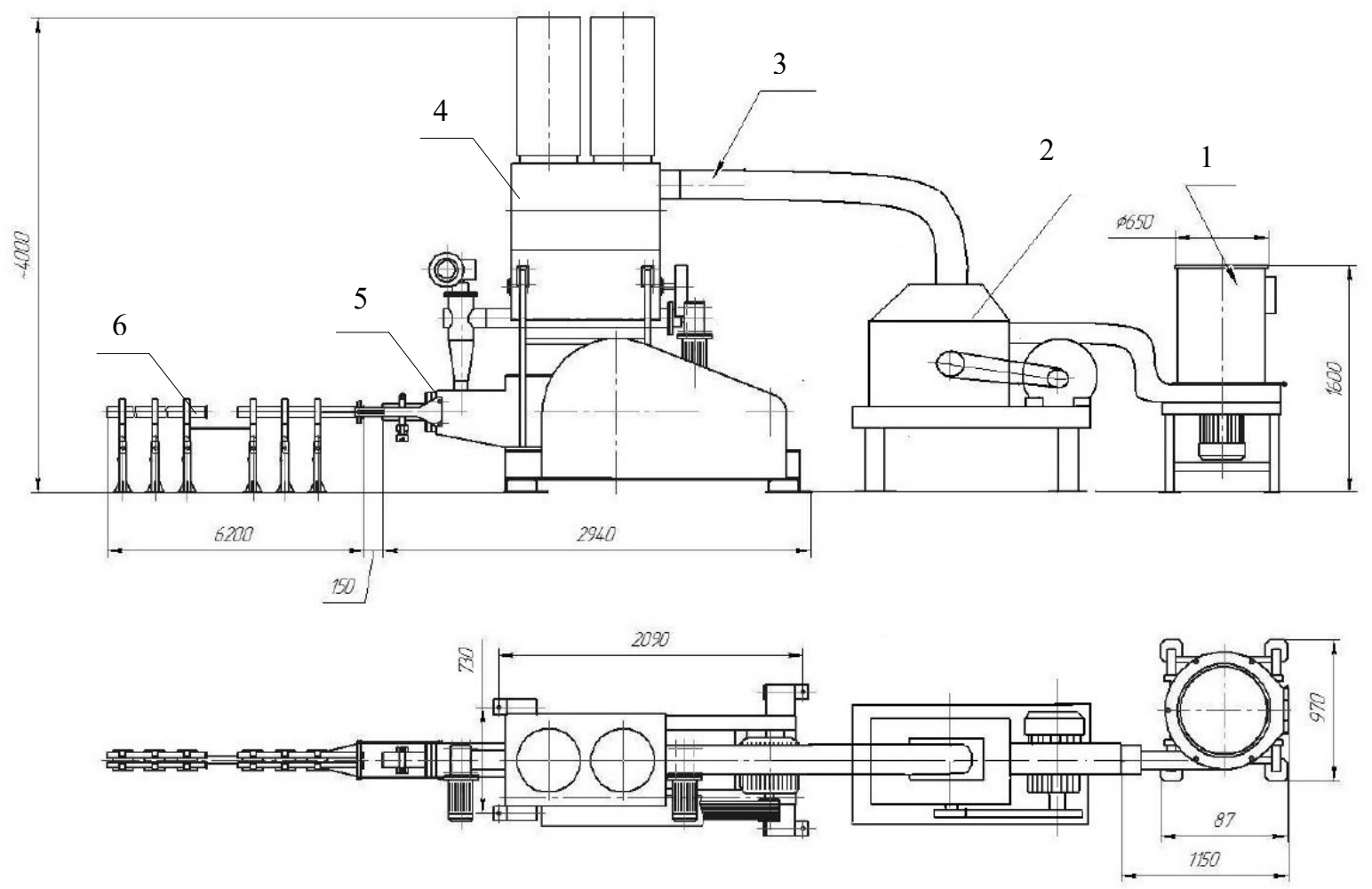

Fig. 5 - Scheme of technological line of production of solid fuel briquettes:

1 - shredder; 2 - heat generator; 3 - corrugation; 4 - dryer; 5 - press briquette; 6 - the briquette divider 


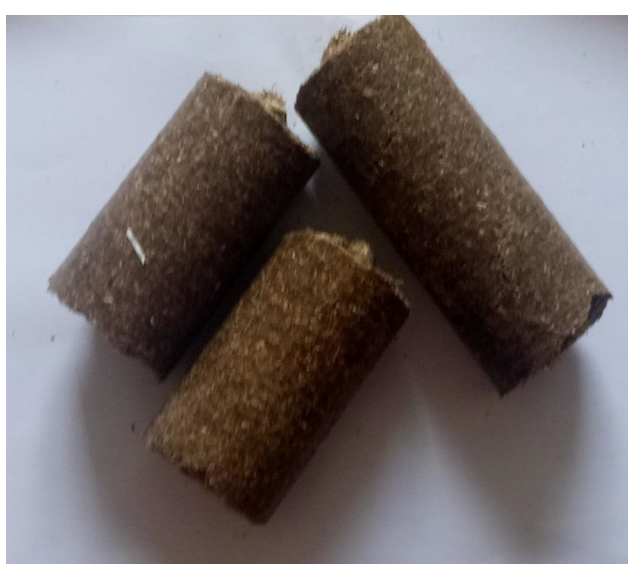

a

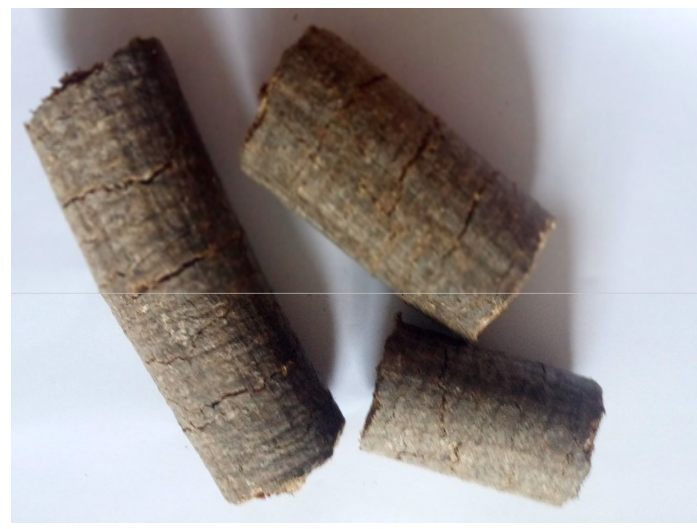

b

Fig. 6 - Photo of samples of fuel briquettes obtained: a - from soybean straw; b - rice husk

Table 3 - Quality indicators of solid fuel briquettes

\begin{tabular}{||l||c|c||}
\hline \multicolumn{1}{|c|}{ Parameters } & \multicolumn{2}{c|}{ Solid fuel briquettes } \\
\cline { 2 - 3 } & of soybean straw & of rice husk \\
\hline \hline Dimensions: length / diameter, $\mathrm{mm}$ & $200 / 50$ & $200 / 50$ \\
\hline \hline Mass fraction of moisture $\left(\right.$ drying at $\left.+40^{\circ} \mathrm{C}\right), \%$ & 1,96 & 2,22 \\
\hline \hline Mass fraction of moisture $\left(\right.$ drying at $\left.+105^{\circ} \mathrm{C}\right), \%$ & 6,58 & 7,24 \\
\hline \hline Ash $\left(\right.$ dry state, $\left.105^{\circ} \mathrm{C}\right), \%$ & 6,90 & 14,13 \\
\hline \hline Sulfur content $\left(\right.$ dry state, $\left.105^{\circ} \mathrm{C}\right), \%$ & 0,246 & 0,108 \\
\hline \hline Total carbon content $\left(\mathrm{dry}\right.$ state, $\left.+105^{\circ} \mathrm{C}\right), \%$ & 47,05 & 41,76 \\
\hline \hline Output of volatile compounds $\left(\right.$ dry state, $\left.+105^{\circ} \mathrm{C}\right), \%$ & 80,20 & 74,11 \\
\hline \hline Lower combustion heat $($ per working state) $\mathrm{kcal} / \mathrm{kg}$ & 3549 & 3192 \\
\hline \hline Higher combustion heat $($ per working state) $\mathrm{kcal} / \mathrm{kg}$ & 3880 & 3502 \\
\hline \hline Lower combustion heat $\left(\mathrm{dry},+105^{\circ} \mathrm{C}\right), \mathrm{kcal} / \mathrm{kg}$ & 3935 & 3586 \\
\hline \hline Higher combustion heat $\left(\mathrm{dry},+105^{\circ} \mathrm{C}\right), \mathrm{kcal} / \mathrm{kg}$ & 4242 & 3868 \\
\hline
\end{tabular}

humidity, dimensions (diameter, length), as well as the correct form. After leaving the working body of the extruder briquette is divided into parts up to $300 \mathrm{~mm}$.

Cooling

In the process of pressing the raw material reaches a temperature of more than $+70^{\circ} \mathrm{C}$. The higher the compression force, the higher the temperature of the briquettes and their better quality. Cooling is required for the final curing of the finished briquettes, making them suitable for storage and transport. In some presses, the briquette moves along the long guide after leaving the molding nozzle. Total cooling time not more than 2 hours (depending on ambient temperature).

\section{Packing}

Making the product look good is an integral part of the production process. Therefore, at the final stage of preparation of the briquettes for sale, they are packed into bags of $25 \mathrm{~kg}$ or plastic bags and stacked on pallets.

The obtained cylindrical forms of fuel briquettes (Fig. 6) were evaluated according to the quality indicators in the laboratory of LLC «Scientific and Service Firm "Ottawa"», the results of the studies are presented in Table. 3.

The quality of fuel briquettes (Table 3 ) is significantly influenced by the humidity, the degree of grinding and the physical and chemical properties of the raw material. When the moisture content of the raw materials is more than $14 \%$ the density of the granules decreases and due to the evaporation of moisture in the granules cracks appear, which reduce their strength. With the reduction of the average particle size of the biomass to 2 $\mathrm{mm}$, the quality of fuel products increases, but it is known from the literature that fine biomass contributes to the firing of the matrix of the briquette presser [14].

The heat of combustion of solid biofuels also exceeds the normative values of European standards at a level not lower than $18 \mathrm{MJ} / \mathrm{kg}$ [5].

Ash content $(0.5 \%)$, normalized by European standards, is practically unavailable for Ukrainian producers, fuel briquettes made from soy straw and husks have higher normalized ash values in accordance with 7 and $14 \%$, which reduces their quality indicators.

\section{Conclusions}

Therefore, biofuel production is relevant for Ukraine, because it has a number of advantages among other types of fuel, because, first and foremost, it minimizes the use of extractive fuel resources, in its impact improves the current state of ecology of Ukraine and potentially affects the development of the domestic fuel industry and related industries.

The primary potential for utilization in the process of processing for bioenergy products is the primary crop waste. The primary source of biomass in the Kher- 
son region is the primary crop waste, namely soybean straw, through increased soybean production and yield. Another type of agricultural biomass waste is secondary waste, which is generated at the processing enterprises of the Kherson region - rice husks.

Processing straw into fuel briquettes can solve many problems. Soybean straw briquettes have a calorific value per unit volume of almost 10 times greater than the feedstock. Briquetting will also solve the issue of storage of this waste regardless of the time of year, with transportation, as well as automate the loading process in the furnace.

The production of biofuels as a specific product can be successfully established both at the enterprises where it will be the main product and at the enterprises whose by-products will be raw materials for its coproduction.

\section{REFERENCES}

1. Pidhotovka ta vprovadzhennya proektiv zamishchennya prirodnoho hazu biomasoyu pri virobnitstvi teplovoyi enerhiyi $v$ Ukrayini : praktichniy posibnik / za red. H. Heletukha. K: Polihraf plyus, 2015. 72 s.

2. Ekolohizatsiya enerhetiki: navchal niy posibnik/Shevchuk V. ya. ta in. K: Vishcha osvita, 2002. 111 s.

3. Enerhetichniy potentsial biomasi v Ukrayini / Lakida P. I. ta in. K: Vidavnichiy tsentr NUBiP Ukrayini, $2011.28 \mathrm{~s}$.

4. Bioenergy Europe: [Veb-sayt]. 2020. URL: https://bioenergyeurope.org/about-bioenergy.html (data zvernennya: 05.02.2020).

5. Haydenko O. M. Tekhnolohichniy protses zahotivli ta vikoristannya roslinnoyi biomasi yak tverdoho biopaliva : monohrafiya. K: Ahrar. nauka, 2017. 144 s.

6. Hutsalenko L. V., Fabiyans 'ka V. Yu. Stan ta osnovni chinniki rozvitku virobnitstva biolohichnoho paliva v Ukrayini ta sviti // Naukovi pratsi Institutu bioenerhetichnikh kul tur i tsukrovikh buryakiv. 2013. Vip. 19. S. 168-174.

7. "Praktichniy posibnik z vikoristannya biomasi v yakosti paliva u munitsipal nomu sektori Ukrayini (dlya predstavnikiv ahropromislovoho kompleksu) / Heletukha H. ta in. // www.bioenergy.in.ua. 2019. URL: http://bioenergy.in.ua/media/filer_public/f5/9c/f59c3f7f-8eca-4b6d-94cd-ffda1150f3ae/biofin.pdf (data zvernennya: 19.12.2019).

8. Derzhavne ahentstvo $z$ enerhoefektivnosti ta enerhozberezhennya Ukrayini: [Veb-sayt]. 2019. URL: https://saee.gov.ua/uk/ae/bioenergy (data zvernennya: 19.12.2019).

9. Kazakova I. V., Kondratyuk N. V. Efektivnist virobnitstva soyi ta rozvitok rinku soyevikh produktiv v Ukrayini $i$ sviti // efektivna ekonomika. 2015. № 5. Odesa, 2020. URL: http://nbuv.gov.ua/UJRN/efek_2015_5_38 (data zvernennya: 16.01.2020).

10. Herasimenko I. Soya v perspektivi: vrozhay $i$ tsini v Ukrayini ta sviti // agravery.com. Odesa, 2019. URL: https://agravery.com/uk/posts/show/soa-v-perspektivi-vrozaj-i-cini-v-ukraini-ta-sviti (data zvernennya: 25.12.2019).

11. LATIFUNDIST.COM: [Veb-sayt]. 2020. URL: https://latifundist.com/urozhaj-online-2019 (data zvernennya: 16.01.2020).

12. Tekhnolohichni osnovi vihotovlennya biopaliva z roslinnikh vidkhodiv ta yikh kompozitiv: monohrafiya / Klimenko V. V. ta in. Kropivnits 'kiy: PP «Eksklyuziv-Sistem», 2017. 162 s.

13. Chuchuy V. P., Umins 'kiy S. M., Inyutin S. V. Al ternativni dzherela enerhiyi . Odesa: TES, 2015. 398 s.

14. Homonay M. V. Proizvodstvo toplivnykh briketov. Drevesnoe syr'e, oborudovanie, tekhnolohii, rezhimy raboty: monohrafiya. M: HOU VPO MHUL, 2006. 68 s.

15. Metodichni vkazivki do vikonannya laboratornikh robit z kursu «Tekhnolohiya biopaliva» dlya studentiv spetsial nosti 181 "Kharchovi tekhnolohiyi» dennoyi i zaochnoyi form navchannya / Ukladachi: T.V. Bordun, O.Ye. Voyets 'ka, I.S. Cherneha, O.H. TSyundik / Za red. prof. V.P. Fedoryaki. Odesa: ONAKhT, 2019. 55 s.

\section{УДК 662.762.2:633.1-027.33}

А.В. Макаринська, канд. техн. наук, доцент, E-mail: allavm2015@gmail.com ORCID: 0000-0003-1879-8455, Researcher ID: C-5217-2016,

Scopus ID: 57192819060

T.М. Турпурова, канд. техн. наук, доцент, E-mail: turpurova.tatyana@gmail.com ORCID 0000-0003-3030-7591, Researcher ID: C-3755-2017

В.В. Булюк, аспірант, E-mail: vbuliuk@gmail.com Кафедра технології комбікормів і біопалива, Одеська національна академія харчових технологій, вул. Канатна, 112, Одеса, 65039, Україна

\section{ВИРОБНИЦТВО ТВЕРДОГО БІОПАЛИВА З ВІДХОДІВ ПЕРЕРОБКИ ЗЕРНА}

\footnotetext{
Анотація

Стаття присвячена питанням виробництва твердого біопалива. Наведена класифікаџія біомаси, яку використовують при виробництві твердого біопалива, за походженням. Визначені основні види відходів зерна у південному регіоні для виробництва твердого біопалива.

В статті наведено аналіз ринку сої у світі та Україні, показано тенденцію зростання обсягів вирощування сої, щзо зумовлене зростанням попиту на харчові та кормові цілі. Проаналізовано показники урожайності сої в Україні та встановлено, щзо Херсонська область є одним з лідерів врожайності сої за 2019 рік. Показано, щзо при вирощуванні сої в Україні отримується значна кількість вторинного ресурсу - соломи, як побічної
} 
продукиії рослинництва. Встановлено, щзо середня врожайність рису Херсонщини переважає по Україні, утворюється велика кількість лузги рисової при переробці рису-сирию.

Визначено фізико-механічні властивості рисової лузги та соєвої соломи. Розглянуто можливість виробництва паливних брикет з даних відходів, наведено технологічну схему виробництва паливних брикетів з відходів, які утворюються на підприємствах переробної промисловості та побічної продукиї рослинництва.

Запроваджено технологію виробництва паливних брикетів з соєвої соломи та рисової лузги на підприємстві Херсонської області, яке займається вирощування та переробкою сої та рису. Визначено показники якості паливних брикетів: вологість, вміст золи, сірки, вуглецю, виходу летких речовин та питомої теплоти згорання. Встановлено, щчо на якість паливних гранул істотно впливають вологість, ступінь подрібнення $i$ фiзико-хімічні властивості сировини. При вологості сировини понад $14 \%$ зменшується щуільність гранул $i$, внаслідок випаровування вологи, в гранулах виникають тріщини, щзо знижують їх міцність. Зі зменшенням середніх розмірів частинок біомаси до 2 мм якість паливних виробів зростає, але дрібна фракція біомаси призводить до зношуванню матриці.

Теплота згорання отриманих твердих брикетів перевищує нормативні значення європейських стандартів на рівні не нижче 18 МДж/кг. Нормована європейськими стандартами величина зольності (0,5\%) практично недосяжна для украӥнських виробників, паливні брикети, виготовлені з соломи соєвої та лузги рису, мають понад нормовані значення зольності відповідно до 7,0 та 14,0 \%, щзо і знижує їх показники якості.

Ключові слова: відходи, лузга рисова, солома соєва, технологія, біопаливо, брикети, якість.

\section{ЛІТЕРАТУРА}

1. Підготовка та впровадження проектів заміщення природного газу біомасою при виробництві теплової енергї в Украйні : практичний посібник / за ред. Г. Гелетуха. К: Поліграф плюс, 2015. 72 с.

2. Екологізація енергетики: навчальний посібник / Шевчук В. Я. та ін. К: Вища освіта, 2002. 111 с.

3. Енергетичний потенціал біомаси в Украйні / Лакида П. І. та ін. К: Видавничий центр НУБіП Украйни, 2011. 28 с.

4. Bioenergy Europe: [Веб-сайm]. 2020. URL: https://bioenergyeurope.org/about-bioenergy.html (дата звернення: 05.02.2020).

5. Гайденко О. М. Технологічний прочес заготівлі та використання рослинної біомаси як твердого біопалива : монографія. К: Аграр. наука, 2017. 144 c.

6. Гуцаленко Л. В., Фабіянська В. Ю.Стан та основні чинники розвитку виробництва біологічного палива в Украӥні та світі // Наукові праці Інституту біоенергетичних культур і иукрових буряків. 2013. Bип. 19. С. 168-174.

7. "Практичний посібник з використання біомаси в якості палива у муніципальному секторі Украйни (для представників агропромислового комплексу) / Гелетуха Г. ma iн. // www.bioenergy.in.ua. 2019. URL: http://bioenergy.in.ua/media/filer_public/f5/9c/f59c3f7f-8eca-4b6d-94cd-ffda1150f3ae/biofin.pdf) (дата звернення: 19.12.2019).

8. Державне агентство з енергоефективності та енергозбереження Украйни: [Веб-сайт]. 2019. URL: https://saee.gov.ua/uk/ae/bioenergy (дата звернення: 19.12.2019).

9. Казакова I. В., Кондратюк Н. В. Ефективність виробництва сої та розвиток ринку соєвих продуктів в Україні $і$ світі // ефективна економіка. 2015. № 5. Одеса, 2020. URL: http://nbuv.gov.ua/UJRN/efek_2015_5_38 (дата звернення: 16.01.2020).

10. Герасименко I. Соя в перспективі: врожай і иіни в Украйні та світі // agravery.com. Odeca, 2019. URL: https://agravery.com/uk/posts/show/soa-v-perspektivi-vrozaj-i-cini-v-ukraini-ta-sviti (дата звернення: 25.12.2019).

11. LATIFUNDIST.COM: [Веб-сайm]. 2020. URL: https://latifundist.com/urozhaj-online-2019 (дата звернення: 16.01.2020).

12. Технологічні основи виготовлення біопалива з рослинних відходів та їх композитів: монографія / Клименко В. В. та ін. Кропивницький: ПП «Ексклюзив-Систем», 2017. 162 с.

13. Чучуй В. П., Уминський С. М., Інютін С. В. Альтернативні джерела енергї. Одеса: ТЕС, 2015. 398 с.

14. Гомонай М. В. Производство топливных брикетов. Древесное сырье, оборудование, технологии, режимы работы: монография. М: ГОУ ВПО МГУЛ, 2006. 68 с.

15. Методичні вказівки до виконання лабораторних робіт з курсу «Технологія біопалива» для студентів спеціальності 181 «Харчові технологї» денної і заочної форм навчання / Укладачі: Т.В. Бордун, О.Є. Воєцька, І.С. Чернега, О.Г. Цюндик / За ред. проф. В.П. Федоряки. Одеса: ОНАХТ, 2019. 55 с.

Received 14.11.2019

Reviewed 02.12.2019
Revised 18.01.2020

Approved 03.03.2020

Cite as Vancouver Citation Style

Makarynska A., Turpurova T., Buluk V. Production of solid biofuels from grain processing wastes. Grain Products and Mixed Fodder's, 2020; $20(1,77)$ : 48-54. DOI:

Cite as State Standard of Ukraine 8302:2015

Production of solid biofuels from grain processing wastes / Makarynska A. et al. // Grain Products and Mixed Fodder's. 2020.

Vol. 20, Issue 1 (77). P. 48-54. DOI:

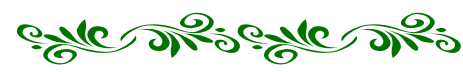

